\title{
Untrepreneurship: \\ Undoing the myth of entrepreneurship as a development apparatus
}

Author:

${ }^{*}$ Ms Maria Smit ${ }^{1}$

Prof. Marius Pretorius ${ }^{1}$

\section{Affiliation:}

${ }^{1}$ University of Pretoria,

South Africa

E-mail:

*maria.strauss.smit@ gmail.com

marius.pretorius@up.ac.za

DOI:

10.15249/14-1-273

Keywords:

critical management studies; entrepreneurship; development; postdevelopment; untrepreneurship

*corresponding author

\section{Abstract}

The current theoretical framing of entrepreneurship includes several diverse phenomena under the same conceptual umbrella, yet the terms are often conflated and used interchangeably. Based on the assumption that anything included under this conceptual umbrella contributes to economic development and job creation, entrepreneurship has become appropriated as a development tool in the Global South, where poverty and unemployment are rife. This study introduces the term 'entrepreneurship as a development apparatus' (EDA) that is defined as the implementation of entrepreneurship support interventions (such as training, incubation and funding) in economically marginalised communities, based on the assumption that these interventions lead to economic development and job creation. EDA is then taken out from under the conceptual entrepreneurship umbrella, and placed in a postdevelopment theory context, showing that insight can be gained when the critical debate on entrepreneurship is moved beyond the constraints of the mainstream entrepreneurship paradigm. Drawing from the development debate this article argues that the current theoretical entrepreneurship paradigm has proven unable to provide answers to the failure of EDA, and thus calls for the rejection of the entire notion of EDA as a form of entrepreneurship.

\section{Introduction}

The current theoretical framing of entrepreneurship includes several diverse phenomena under the same conceptual umbrella: from opportunity entrepreneurs to necessity entrepreneurs to survivalist entrepreneurs; from small to medium to micro- 
enterprises; rural entrepreneurship, corporate entrepreneurship and social entrepreneurship; to name but a few. In the process of establishing an inclusive definition, the term has come to mean both everything and nothing (Da Costa \& Silva Saraiva, 2012:589). The terms 'entrepreneur' and 'entrepreneurship' have been misappropriated to the extent that they now include more or less all of humanity (Poole, 2018:41). 'Entrepreneur' is by no means a homogenous concept, but mainstream research continuously conceptualises it as a uniform phenomenon, and in doing so protects several mainstream assumptions from being questioned (Calás, Smircich \& Bourne, 2009:553).

One such assumption is that entrepreneurship is a silver bullet for job creation and economic growth. This narrative has become normalised in the mainstream entrepreneurship discourse - both scholarly and public (Authors, 2020). Based on this assumption, development organisations and governments in the developing world have implemented numerous policies and interventions to stimulate the small- and mediumsized enterprise (SME) sector, believing that it is a catalyst for growth, job creation and poverty reduction (Poole, 2018:35). However, only a handful of these SMEs survive past the first three years of their existence and only show potential to contribute significantly to job creation and economic growth. In this way, entrepreneurship has become appropriated as a development apparatus, a phenomenon especially observed in the Global South. The term 'entrepreneurship as a development apparatus' (EDA) is introduced in this article, distinguishing this phenomenon from other phenomena included under the conceptual umbrella. EDA is defined as the implementation of entrepreneurship support interventions (such as training, incubation and funding) in economically marginalised communities, based on the assumption that these interventions lead to economic development and job creation. Governments and development institutions support EDA across the Global South.

Critical entrepreneurship scholars have for some time called for the reframing of entrepreneurship from a purely economic to a social change activity (i.e. Calás et al., 2009; Steyaert \& Katz, 2004b), yet mainstream entrepreneurship theory fails to do so and continually imposes presupposed constructions onto an ambiguous social reality (Achtenhagen \& Welter, 2007:198; Alvesson \& Deetz, 2000:55; Alvesson \& Willmott, 2003:23; Calás et al., 2009:553; Tedmanson, Verduyn, Essers \& Gartner, 2012:532; Urban, 2010:42). As a consequence, even if the failure of EDA is recognised, research, examining the flawed implementation of entrepreneurship policies, programmes and interventions, remains limited. The structural roots and conceptual framing of everything included under the entrepreneurship umbrella are never questioned.

The theoretical physicist Albert Einstein noted that the answers to a problem cannot be sought within the very paradigm that created the problem (Esteva \& Escobar, 2017:2569). This article suggests that the current, largely positivist theoretical grounding of mainstream entrepreneurship theory is inadequate to address the large-scale failure of EDA in the Global South. When entrepreneurship is appropriated as a development apparatus, it becomes imperative to reframe it conceptually in a development context. In not doing so, EDA remains exempted from the rich, ongoing discourse on development, 
alternative development and post-development that may potentially inform the failure of entrepreneurship to live up to its promise of job creation and economic growth. It is proposed that when EDA is viewed from a post-development perspective, the answers to the problem become surprisingly obvious.

The contribution of this article is twofold. Firstly, it advances the nascent field of critical entrepreneurship studies by viewing mainstream entrepreneurship theory through a post-development theory lens. Secondly, it presents EDA as a complex, interdisciplinary field of study that begs to be researched beyond the constraints of mainstream entrepreneurship theory.

\section{A short overview of development and development theory}

In 1949, the then President of the United States of America, Harry Truman, said in his inaugural address:

More than half the people of the world are living in conditions approaching misery. Their food is inadequate. They are victims of disease. Their economic life is primitive and stagnant. Their poverty is a handicap and a threat both to them and to more prosperous areas.

(Brigg, 2002:424)

This early mainstream vision of development is an extension of modernisation theory and paints a picture of an 'undeveloped' world in dire need of being rescued from an undesired, unpleasant state of misery and poverty (Matthews, 2005:97). The 'development project' is presented as the vehicle through which the 'underdeveloped' world would be rescued and elevated to a superior state of 'development'. Modernisation theory constructs a binary, dichotomous world where the characteristics of "us, the developed (who have)" are contrasted with "them, the underdeveloped (who need)" (Esteva \& Escobar, 2017:2564; Matthews, 2005:98). This view of development assumes the characteristics of the 'developed' world to be the ideal state to which the 'underdeveloped' world must aspire.

By the late 1970s, neo-liberalism begins to inform mainstream development theory. The key premise that distinguishes it from modernisation theory is that governments are considered a hindrance to economic growth and should therefore not interfere with development (Matthews, 2005:100). International organisations such as the International Monetary Fund and the World Bank thus begin implementing programmes to liberalise the economies of the 'underdeveloped' world and elevate them to a state of 'development'. Both modernisation theory and the influence of neo-liberalism assume the qualities, characteristics, values and institutions of the 'developed' world to be universal and desired by the 'underdeveloped' world. The term Global South has emerged to refer to the spaces and peoples outside of North America and Western Europe that are associated with this undesired state of 'underdevelopment'. 
Africa's colonial history has led to the view that "the continent is essentially inadequate, a place of systemic failure in terms of its ability to engage with and partake in the modern world" (Andreasson, 2017:2635). With the end of colonialism, Africa is (presumed to be) hungry for answers on how to become more 'developed', and thus the modern development project is born. The colonial discourse strongly influences the development narrative (Wilson, 2017:2686), and the answers brought by 'development' are deeply rooted in the principles of neo-liberalism.

Matthews (2005:109) identifies three assumptions that are made across the different schools of development theory:

- The world consists of 'developed' and 'less developed' regions, which can be compared to one another in terms of their level of development;

- Western societies are 'developed', other societies less so; and

- In aiming to develop, the 'less[-]developed' regions must aim to transform their societies in such a way that they are more similar to the societies of the 'developed' regions in certain key aspects.

By the 1980s, the development community became disillusioned by 'development' and recognised the "foolishness of adopting a universal definition of the good life" (Esteva \& Escobar, 2017:2561). The dark side of 'development' can no longer go unheeded: increased cultural homogenisation (specifically Westernisation); environmental destruction; the failure to deliver on promises such as poverty reduction, income inequity, economic growth and an increase in standards of living (Matthews, 2004:377). The realisation is that the mainstream view of 'development' cannot be regarded as a panacea for all people living in poverty (Andreasson, 2017:2644). Critics call for alternative approaches to development that draw from, amongst others, dependency theory, the human development approach and sustainable development (Matthews, 2005:101-108). These alternative approaches involve a more bottom-up, people-centred, participatory approach to development, the modernisation of endogenous traditions and a focus on human development indexes as a measure of development (Nederveen Pieterse, 1998:351). These alternative development approaches propose different means to reach a universally desired state of development, but the premise of 'development' in itself is not questioned and criticised. To a large extent, these alternative development criticisms have been co-opted in the mainstream development discourse and practice over the past decades (Nederveen Pieterse, 1998:344).

By the early 1990s, several scholars voiced concern that 'development' has not only failed but is doing more harm than good (Matthews, 2004:373) and that the so-called beneficiaries should rather be considered victims of development (Demaria \& Kothari, 2017:2589). These scholars move beyond critiquing the different approaches to development to questioning the underlying premise, structure and motives of development (Nederveen Pieterse, 2000:176), specifically the structural roots in modernity, capitalism, state domination and patriarchy (Demaria \& Kothari, 2017:2589). Post-development theory emerges and calls for the radical rejection of the entire development paradigm, theory 
and practice (Demaria \& Kothari, 2017:2593). Escobar (1995:215) summarises the main premises of post-development theory as follows:

- an interest not in development alternatives but in alternatives to development, thus a rejection of the entire paradigm;

- an interest in local culture and knowledge;

- a critical stance towards established scientific discourses;

- the defence and promotion of localised, pluralistic grassroots movements.

Since the publication of The Development Dictionary in 1992, more than one strand of post-development theory has emerged. Ziai (2004) identifies two strands: neo-populism and sceptical post-development. Neo-populism can also be seen as 'anti-development' that rejects the entire development paradigm while romanticising endogenous culture, tradition and community. The sceptical approach to post-development "recognises the political and economic power structures within which any fruitful debate on radical alternatives to the status quo must be located" (Andreasson, 2017:2635).

The critique against mainstream development theory is not limited to only one school of critique or even one strand of post-development critique. Post-development theory itself has also been widely discussed and critiqued (Ziai, 2004:1045). What can be learned from seven decades of debate in development theory is that a radical critique of mainstream development theory has advanced and enriched the field as a whole. Post-development theory thus provides a tool for radically deconstructing mainstream development theory, exposing the assumptions inherent in the development ideology (Harcourt, 2017:2715).

\section{The entrepreneurship theory impasse}

The normative capitalist ideology is built on the assumption that the entrepreneurial enterprise is the only possible model for generating wealth, income and employment in society (Da Costa \& Silva Saraiva, 2012:609) and therefore "the more entrepreneurs the merrier" (Verduijn \& Essers, 2013:614). The mainstream entrepreneurship ideology further drives the assumption that, given a chance, anyone can be a successful entrepreneur with an ever-expanding wealth of choice and economic security (Fairclough, 2013:16) and that entrepreneurship can be taught (Kuratko, 2005:580). Because of the perceived relationship between entrepreneurship and economic growth, and the perceived relationship between economic growth and development, entrepreneurial development policies and initiatives are also implemented to foster the entrepreneurial capabilities of societies in the 'underdeveloped' world (Kuada, 2015:148).

This interest of policymakers and politicians in 'entrepreneurship' as a panacea for reviving failing economies has led to ideological ambiguity in the term (Steyaert \& Katz, 2004a:188). What is more, the concepts included under the entrepreneurship umbrella are applied without any consistency, expecting the same results in terms of economic growth and job creation from anything and everything labelled 'entrepreneur' (Poole, 2018:35). In a Global South context, for instance, the term is appropriated in referring 
to a phenomenon like 'corporate entrepreneurship', and also to EDA, from necessity to opportunity entrepreneurs, from high-growth enterprises to survivalists, and everything in between. The current theoretical grounding of the entrepreneurship discourse fails to interrogate the assumption that all types of entrepreneurship are essentially the same, and that it can be expected to contribute equally to job creation and economic growth (Smit \& Pretorius, 2021).

EDA is hailed as a panacea for job creation and economic growth globally, yet it fails to create any empowerment or upward mobility for the marginalised communities it aims to emancipate and does not contribute significantly to job creation (Honig, 2017:453; Naudé, 2011; Shane, 2009). The mainstream entrepreneurship narrative has normalised the assumption that entrepreneurship (in all its forms) is a positive economic activity that is necessarily a successful vehicle for economic growth and job creation. Any failure of entrepreneurship to deliver on this promise is viewed from a positivist, performative perspective. The very theoretical grounding and conceptualisation of the mainstream entrepreneurship ideology are never questioned. In other words, the assumption is that anything and everything included under the entrepreneurship umbrella is a desirable given, and research remains limited to studies that contribute to the improved effectiveness or that build a better model or understanding of the entrepreneurship phenomenon (Fournier \& Grey, 2000:88). These uncritical, performative studies that aim to increase the perceived value of EDA as a catalyst for economic growth and job creation have become supportive of political hegemony and epistemic violence (Authors, 2020).

Internationally, a handful of scholars have become critical of the entrepreneurship ideology. These studies, inter alia, highlight how the homogenous conceptualisation of 'the entrepreneur' can lead to exploitation and ideological hegemony (i.e. Achtenhagen \& Welter, 2007; Calás et al., 2009; Da Costa \& Silva Saraiva, 2012; Jones \& Murtola, 2012; Ogbor, 2000; Verduijn, Dey, Tedmanson \& Essers, 2014) and that insights can be gained from reframing entrepreneurship as largely an economic activity with possible social outcomes, to entrepreneurship as a social activity with several possible outcomes (Calás et al., 2009:553). However, none of these critical studies acknowledges the EDA phenomenon, and it is thus not explicitly included in the rich, ongoing debate around development, alternative development and post-development.

This article argues that mainstream entrepreneurship theory - and EDA in particular - had entered the same theoretical impasse that mainstream development theory encountered in the 1980s when critical development theorists concluded that "no amount of improved implementation will be useful; rather we need to reconsider the ideas informing the Project" (Matthews, 2005:96). Post-development goes beyond merely proposing alternative development interventions by calling for the rejection of the entire notion of development (Demaria \& Kothari, 2017:2593). Drawing from the development debate this article argues that the current theoretical entrepreneurship paradigm has proven to be unable to provide answers to the failure of EDA, and thus calls for the rejection of the entire notion of EDA as a form of entrepreneurship. 
One critique against post-development theory is that it rejects the notion of development yet fails to put alternatives to development on the table (Ziai, 2017:2548). It can be argued, however, that even if post-development theory fails to construct alternatives to development, it does force a change in the mainstream development discourse by challenging the assumptions upon which the development ideology is built (Andreasson, 2017:2643). Post-development thus proves a flexible platform for critique within the broader development framework. Drawing from post-development theory, the aim of this article is not merely to provide a dualistic opposition to mainstream entrepreneurship theory, but opening a wider, dynamic, critical debate of EDA from a post-development perspective. By subjecting mainstream entrepreneurship theory to post-development theory critique, this study extends the nascent field of critical entrepreneurship studies. It furthermore calls for the rejection of the entire notion of EDA as a successful vehicle for job creation and economic growth. Even if the outcome of a critical debate resulting from this study does not lead to the outright rejection of EDA, it will at the very least contribute to the acceptance of EDA based on theoretical reasoning rather than the current ideological assumptions.

\section{Aim and objective}

By introducing EDA and subjecting entrepreneurship theory to the critique of postdevelopment theory, this study aims to do the following:

- Reassess the ontological and epistemological assumptions inherent in mainstream entrepreneurship theory by drawing attention to EDA.

- Provide an alternative lens for critique against mainstream entrepreneurship theory.

- Extend the debate on entrepreneurship theory and praxis beyond the constraints of the mainstream entrepreneurship paradigm.

\section{Applying post-development critique to entrepreneurship theory}

In the following section, the main arguments of post-development theory are laid out in a simplified manner and applied to EDA. In doing so, the assumptions inherent in mainstream theory - and specifically EDA - are highlighted, showing that insight can be gained when the critical debate on entrepreneurship is moved beyond the constraints of the mainstream entrepreneurship paradigm.

\subsection{Theoretical grounding and assumptions underlying mainstream development and mainstream entrepreneurship theory}

Early development theory, an extension of modernisation theory, presents a dichotomous, unequal world: on the one hand, an 'underdeveloped' world in dire need to be rescued from an undesired, unpleasant state of misery and poverty, and on the other hand the 
'developed' world that presents the ideal to which all societies must aspire (Matthews, 2005:97). Development is introduced as the vehicle through which the 'underdeveloped' world can be rescued and elevated to a superior state of 'development'. Early mainstream development theorists share the consensus that 'underdevelopment' is the cause of global inequality and merely differ in their prescription of what development interventions would address the problem and how these interventions should be implemented (Demaria \& Kothari, 2017:2592). The desirability of development and the assumptions underlying the construct are not called into question. Even before the introduction of post-development theory, one of the earliest critiques against mainstream development theory is that it is built on several taken-for-granted presumptions and that the prevailing positivist orthodoxy creates a crisis (Harriss, 2005:18). Development theory and practice are furthermore criticised for legitimising the imposition of its ideology by presenting development theory as 'science' (Nederveen Pieterse, 1998:360). This 'science' reduces the concept of development to "linear, unidirectional material and financial growth" (Demaria \& Kothari, 2017:2593).

Post-development theory introduces the idea that the failure of the global development project is not to be sought in the policies, instruments or indicators that are implemented to bring about this linear, unidirectional growth. Rather, the possibility that the theoretical conceptualisation of development is inherently flawed has to be investigated. Postdevelopment theorists have concluded that the solution to the development conundrum can no longer be sought in the paradigmatic frame that created it (Esteva \& Escobar, 2017:2569). Transformative alternatives to the dominant paradigm have to be pursued (Demaria \& Kothari, 2017:2589). Post-development theory is therefore not interested in more development alternatives, but rather in alternatives to development (Escobar, 1995:215).

Critical entrepreneurship scholars call for the ideological scrutiny of mainstream entrepreneurship theory (Ogbor, 2000:611). They have highlighted several unsubstantiated theoretical assumptions underlying the ideology of entrepreneurship (Alvesson \& Deetz, 2000:55; Alvesson \& Sandberg, 2013:129; Alvesson \& Willmott, 2003:23; Bygrave, 2007:20; Urban, 2010:42). For instance, entrepreneurial diversity is backgrounded (Ogbor, 2000:629) and the terms for different phenomena included under the entrepreneurship umbrella are used interchangeably and inconsistently (Poole, 2018). As a result, the entrepreneurship ideology drives the assumption that all types of entrepreneurship are vehicles through which people can be lifted out of poverty (Authors, 2020). Mainstream entrepreneurship research also places an exaggerated emphasis on positivist ontologies and the associated quantitative methodologies (Bygrave, 2007:25). The field lacks methodological diversity and rigour (Neergaard \& Ulhoi, 2007:1). By describing observed phenomena through mathematical means in a quantitative method, researchers assume that they have created knowledge (Van der Linde, 2016:38), and the knowledge is presented as indisputable science. This "fetishisation with positivism" (Ruggunan, 2016:112) may be producing research that is technically competent yet is becoming increasingly formulaic and dull (Alvesson \& Sandberg, 2013:130). The positivist paradigm not only fails to question the assumptions underlying established literature (Alvesson \& 
Sandberg, 2013:129; Bygrave, 2007:20) but it proves grossly inadequate to understand and explain the complexity of the entrepreneurial phenomenon (Ogbor, 2000:623). Despite regular calls for expanding the type of research designs and analytical approaches in entrepreneurship studies, qualitative studies remain underrepresented in mainstream journals globally (Neergaard \& Ulhoi, 2007:1-2) and the Global South (Authors, 2020).

The repeated and abysmal failure of EDA impels scholars to recognise that the reigning paradigmatic dominance may not lead to the betterment of civil society, but merely to the maintenance of an academic institutional status quo (Goldman, 2016:5). The critique of EDA has to move beyond seeking alternative ways of implementing policies, instruments and indicators for bettering entrepreneurship. Answers cannot be found within the same paradigmatic frame that created the problem. Merely redefining entrepreneurship to include all types of social phenomena (such as necessity entrepreneurs or survivalist entrepreneurs) will not bring about the paradigmatic break needed to shed light on the failure of EDA to contribute significantly to job creation and economic development. Drawing from post-development theory, this study propositions that:

P1: The current conceptual frame of entrepreneurship is grossly inadequate to explain the complexity of the EDA phenomenon.

\subsection{EDA as a Eurocentric construct}

In mainstream development theory, it is assumed that societies can - and want to break free from the perceived misery in the 'underdeveloped' world by adopting the more desirable characteristics of 'the West'. It is presented as a science-based method for changing the 'backward' communities in the Global South to look more like the Western world. The qualities and characteristics of societies, particularly North America and Europe, are promoted as the qualities that societies in the underdeveloped world have to aspire to in order to become 'developed' (Matthews, 2005:97-100). The motto of development is "(playing on words of the Lord's Prayer), 'on Earth as it is in the West" (Sachs, 2017:2561). Mainstream development is thus structurally rooted in "modernity, capitalism, state domination, patriarchy" (Demaria \& Kothari, 2017:2596).

\subsubsection{EDA as an overtly capitalist mechanism}

The development model of a 'better' society is based on capitalist models from an industrial world. The capitalist dream promises "increasing prosperity without limits, an ever[-]expanding wealth of choice, possibility and opportunity, security and comfort in old age" for all, even marginalised groups (Fairclough, 2013:16). However, capitalism is leading to a widening gap between rich and poor and the promise of development to close the gap has been "rendered implausible" (Ziai, 2017:2548). From a critical perspective it has been concluded that capitalism is not the almighty and omnipresent monolith that it presents itself to be and that the current system needs to be repaired or replaced (Esteva \& Escobar, 2017:2571; Fairclough, 2013:16).

The mainstream entrepreneurship discourse also lends overt ideological support to capitalism. As a mechanism of capitalism, entrepreneurship is hailed as a panacea 
for economic emancipation for everyone, even the economically marginalised. Several critical entrepreneurship studies have shown how entrepreneurship has the power to exploit, destruct and oppress (i.e. Da Costa \& Silva Saraiva, 2012; Jones \& Murtola, 2012; Verduijn et al., 2014). These studies illustrate how research downplays this dark side of entrepreneurship when it, in fact, consistently and pervasively prevents emancipation from taking place (Verduijn et al., 2014). Jones and Murtola (2012) regard it as 'blind optimism' to assume that entrepreneurship will necessarily lead to the recognition and liberation of marginalised societies. They argue that entrepreneurship should rather be considered as an act of finding new ways to exploit these societies. However, studies that militate against the unequal, exploitative nature of capitalism are still the exception and entrepreneurship is increasingly romanticised and eulogised (Tedmanson et al., 2012:532).

The limitations of EDA as an overt capitalist mechanism have to be recognised, drawing from post-development theory. This study propositions that:

P2: EDA is and will remain unable to lift marginalised communities in the Global South out of poverty and close the gap between rich and poor.

\subsubsection{Tainted with colonialism}

The concept of development was conceived of in a Western context. From this perspective, Western society is held as the universal standard of development against which other, less-developed societies are measured. Programmes and projects are implemented to transform the 'underdeveloped' societies to look more like the universal standard - the Western society. In this manner 'development' merely reproduces the colonial ideology of European superiority (Harriss, 2005:17; Ziai, 2013:128). From a postdevelopment perspective, development is criticised for colonising the minds, hearts and imaginations of the Global South, this time using 'modern science' to naturalise the idea of Westernisation (Nandy, 1997).

Ogbor (2000) critically examines entrepreneurship theory to determine which societal myths and ideologies are perpetuated in the conventional discourse. He has found that the predominant discourse in entrepreneurship research is reproducing the myth of 'the entrepreneur' as a white, dominant, rational, European/North American, male hero and that very few studies have challenged these ideological stereotypes underlying mainstream entrepreneurship theory.

From a post-development perspective, it is argued that EDA is overtly a colonial project. The idea of Westernisation, using the science of entrepreneurship theory, is naturalised and promoted through the promise of emancipation from poverty.

The rejection of the mainstream entrepreneurship ideology as a colonial construct, from a neo-populist post-development perspective, can be considered a cinch. However, rejecting entrepreneurship outright as an undesirable activity because of its Eurocentric nature does not shed sufficient light on the complexity of the phenomenon observed in practice. It is important to take cognisance of the critique against post-development theory in this regard. A counterargument to the post-development critique is that the 
so-called 'underdeveloped' world seems to desire development and is keen to access the modern conveniences associated with development (Matthews, 2017). Some postdevelopment theorists attribute this to the second form of colonialism - the colonisation of the mind (i.e. Nandy, 1997). They present a picture of "passive victims of development who had development imposed upon them" (Ziai in Matthews, 2017:8). However, Matthews makes a good argument that the people in the Global South are not merely "victims of mental colonisation who mindlessly copy everything they associate with the West" (Matthews, 2017:12). Rather, development is desired because the lifestyle of those in the industrialised West has come to be associated with dignity (Matthews, 2017:13). Previously marginalised groups associate the perceived privileges inherent in a state of 'development' with a sense of redress for past injustices (Matthews, 2017:11).

The mainstream discourse on entrepreneurship generally regards it as the cornerstone of economic growth, income and employment creation (Da Costa \& Silva Saraiva, 2012:588). This discourse holds entrepreneurship as a mass phenomenon and creates the impression that, through entrepreneurship, anyone can realise themselves professionally (Da Costa \& Silva Saraiva, 2012:605). EDA furthers this ideology by promoting entrepreneurship as a silver bullet for job creation and poverty alleviation in the Global South. Based on this narrative flowing from the mainstream entrepreneurship ideology, entrepreneurship is desired by marginalised communities in the Global South: not as a white, male, Eurocentric concept, but as a guaranteed ticket out of poverty, a silver bullet for economic emancipation, and a vehicle for the redress of past injustices. However, an overwhelming number of start-up enterprises in the Global South fail within the first three years of existence. EDA proves unable to deliver on the promise of redressing past injustices. This study propositions that:

P3: Through continuing to sell EDA as an instrument of emancipation to marginalised communities, the mainstream entrepreneurship narrative is making itself guilty of sowing seeds of discontent.

\subsubsection{The (ignored) endogenous context}

Mainstream development theory fails to take into account the endogenous context of the societies that are being 'developed' (Escobar, 1992). Development is a cultural, political, economic and historical process (Harcourt, 2017:2707), not merely a single, homogenous, linear push to modernity. This multi-dimensional character of development makes it impossible to assume that "analysis and answers can be derived ... from Western science" (Harriss, 2005:34). When entrepreneurship is appropriated as a development apparatus, answers cannot merely be sought in Western science and theory. However, the bulk of the empirical studies done on the link between entrepreneurship and economic development are conducted in Global North economies in North America and Europe, and the findings of these studies have proven of limited use for answering questions about economic development in the Global South (Naudé, 2011:37). Critical entrepreneurship scholars are questioning its utility even in the Global North. There is a particular lack of scientific debate on African entrepreneurship, and there is, in fact, very little research that confirms 
that entrepreneurship does indeed lead to economic growth in an African context (Naudé \& Havenga, 2005:101, 107). Mainstream entrepreneurship theory, similar to mainstream development theory, fails to take into account the needs, values and conditions of the so-called beneficiaries (Hamilton, 2019:8) or the politics and relations of power where these ideas are implemented (Ziai, 2013:129). Post-development theory has shown that social inequity has "rarely been dealt with successfully" in this top-down approach (Ziai, 2013:129).

From a post-development theory perspective, the failure to take into account the endogenous cultural, social, political and economic context of the societies where entrepreneurship is presented as an undisputed silver bullet for economic growth and job creation can no longer be accepted. This study argues that the failure to take into account the endogenous context has to be considered as (at least partially) causal of the failure of EDA. Answering the academic call for more research in an African context does not merely mean applying Western scientific models in an African context. Postdevelopment theory argues that the alternative proposals to address poverty alleviation and human development should be sought on local soil, from traditionally marginalised, non-capitalist spaces (Demaria \& Kothari, 2017:2593). Research in South Africa, including entrepreneurship research, should actively seek, promote and set into motion the endogenous, non-dominant modernities that have for too long been ignored and sidelined (Esteva \& Escobar, 2017:2570). Post-development has introduced these indigenous alternatives as viable and credible alternatives to the mainstream, naturalised, takenfor-granted assumptions inherent in mainstream theory, even when these alternatives seem unrealistic and radical at the onset (Demaria \& Kothari, 2017:2589). This study propositions that:

P4: Alternatives to EDA as a vehicle for job creation and economic growth have to be sought within the endogenous, non-dominant modernities.

\subsection{Environmental destruction}

In this regard, post-development has a simple critique against development theory: that attaining a middle-class lifestyle for the majority of the world population is not only impossible, but it is also undesirable (Matthews, 2005:109; Nederveen Pieterse, 1998:360). Increased financial means increased consumption, and the earth's resources will not be able to sustain the consumption of a global middle class. Post-development has shown how "the politics of poverty reduction often comes at the price of increasing inequality and environmental degradation" (Sachs, 2017:2565).

Entrepreneurial success is measured in terms of growth and profitability (Zhao, Seibert \& Lumpkin, 2010:384). A growing number of successful entrepreneurs would thus mean increased consumption that would place devastating pressure on a limited planet. In promoting entrepreneurship as a silver bullet for economic emancipation for a large number of the world population, EDA fails to consider the degrading impact that an 
ever-growing, successful entrepreneurial force would have on the environment. From a post-development perspective, this study propositions that:

P5: The ideology that anyone and everyone could become a successful entrepreneur is not only based on fallacious assumptions, but the impact of this ideology on the environment would be devastating.

\subsection{Legitimising the relevance of mainstream entrepreneurship theory}

Development theory creates an expectation that taking on the qualities of the Global North will exterminate poverty and inequality. However, it becomes clear that development fails to deliver on this promise of elevating the majority of the world population to a Western standard of a middle-class lifestyle (Matthews, 2005:109; Nederveen Pieterse, 2000:175). By the 1980s, the failure of the development project was widely recognised by practitioners and scholars alike (Esteva \& Prakash, 1998:280). Sachs (1992:1) declares development theory a "ruin in the intellectual landscape" and Esteva suggests it should be studied as archaeology, since "only an archaeological eye could explore the ruins left by development" (Esteva \& Escobar, 2017:2652). However, the recognition of development's failure did not result in development's end, but rather in the reinvention of the field in the 1990s (Harriss, 2005:23). The initial goals for development are postponed indefinitely (Esteva \& Prakash, 1998:282) and make way for a development project that is largely focused on meeting basic needs and survival rather than progress. In doing so, mainstream development theory can legitimise its relevance. To illustrate how the focus of development to this day remains on survival rather than progress, Sachs unpacks the United Nations' Sustainable Development Goals (SDGs) adopted in 2015 and concludes that it would be more fitting to call the SDGs the SSGs - Sustainable Survival Goals (Sachs, 2017:2575-2576). He finds that the SDGs "try to secure a minimum for a dignified life universally" rather than promoting the expectation of progress and the extermination of poverty and inequality.

This pattern is repeated in mainstream entrepreneurship theory. One could not be blamed for expecting that the chronic failure of the entrepreneurship ideology to lead to significant economic emancipation or poverty alleviation would result in the end of decades of EDA. However, the recognition of EDA's failure merely resulted in the extension of the conceptual boundaries of entrepreneurship. Once a theory that brought to mind images of Elon Musk or Patrice Motsepe, the entrepreneurship umbrella has been reinvented to include contradictory terms like 'necessity entrepreneur' or 'survivalist entrepreneur'. This study propositions that:

P6: Including EDA under the broader entrepreneurship framework is an attempt to legitimise the field and fails to contribute to upward mobility for the so-called beneficiaries. 
At the onset, development was measured by a country's gross national product or per capita income (Sachs, 2017:2577; Ziai, 2013:127), thus reducing the measure of 'development' to the income or commodities that people possess (Anand \& Sen, 1994:1). Mainstream development is thus criticised:

as an economic rationality centred around accumulation, a capitalist logic of privileging activities earning money through the market (and disvaluing all other forms of social existence), and the idea of 'homo economicus' (whose needs for consumption are infinite).

(Ziai, 2017:2547)

By imposing one universally defined picture of the 'good life' and excluding all others, development is criticised for being "radically inhospitable" (Esteva \& Escobar, 2017:2561).

Mainstream development underestimates the diversity and complexity of the development construct (Nederveen Pieterse, 1998:347) and is criticised for ignoring the multidimensionality of life (Esteva \& Escobar, 2017:2565). Challenges like misery, inequity, poverty and corruption persist even in the so-called 'developed' world - despite material well-being (Matthews, 2005:108). Similarly, many people in the Global South are fulfilled and happy - despite poverty. The qualities of the 'good life' are not universal, and the measures of a good living standard look different in each society (Ziai, 2013:128). This critique of mainstream development theory has, to some extent, been co-opted into the development discourse, as can be seen by the implementation of measures such as the Human Development Index (Ziai, 2013:127).

Although not a post-development theorist per se, the economist and Nobel laureate Amartya Sen's capability approach makes an important advance on this narrow, mainstream view of development (Hamilton, 2019:7) and it is worth taking note of his work in the context of EDA. According to the capability approach, the objective of development has to be "expanding the freedoms that people enjoy" (Sen, 2001:9), not merely their wealth and income. When this becomes the objective, development is implemented to expand the capacity and capability of citizens to determine what a good life would look like for them, and expanding their power to create it (Hamilton, 2019:9). Although wealth and income are a means in which people can expand their capabilities, it cannot be considered a direct measure of a good life (Anand \& Sen, 1994:1).

Mainstream entrepreneurship theory imposes a universally developed image of a 'good entrepreneur' or a 'successful enterprise' onto an ambiguous social reality. Firm performance is measured in terms of indicators such as firm survival, growth and profitability (Zhao et al., 2010:384). The economic emphasis behind the entrepreneurship construct (as an overt capitalist mechanism) limits the measure of success to economic indicators. Research remains determined to reproduce performative studies that merely promote increased growth, growth intention and profitability - failing to conceptually frame entrepreneurship as a development activity prevents critical questions from being asked. One such question is: what assumptions is the mainstream entrepreneurship theory making when defining 'improvement' or 'growth'? 
One assumption inherent in EDA is that people want to be entrepreneurs and that their entrepreneurial intention can be improved through interventions such as training and incubation. However, by including EDA in a conceptual framework that regards entrepreneurship as a purely economic activity, it fails to take into account the devastating psychological effects of the failure of EDA on the so-called beneficiaries. EDA is presented as a guaranteed solution to job creation when data shows that barely one in four beneficiaries will grow a business that survives past their first three years of existence. Scholars, practitioners and politicians alike have to consider that EDA neither expands the capacity and capability of citizens to determine what a good life would look like for them nor expands their power to create it. This article argues that EDA could be accused of limiting the so-called beneficiaries' freedoms and doing more harm than good.

It is not suggested that the project of improving the lives of people living in poverty and misery should be abandoned (Matthews, 2004:376). However, EDA has to recognise that the idea of what should be desired and is sufficient cannot be decided from an affluent, Western perspective (Ziai, 2017:2548). Presenting EDA as the blanket solution for economic growth and job creation is proving to be a fallacy. Future research should heed the call by post-development to "hospitably embrace the thousand different ways of thinking, being, living and experiencing the world that characterise reality" (Esteva \& Escobar, 2017:2561). This study propositions that:

P7: EDA is limiting the freedoms of the very groups it is aiming to emancipate and is doing more harm than good.

\subsection{The exploitative nature of EDA}

Discourses are mechanisms for maintaining certain power relations within a society (Jäger \& Maier, 2009:36); done by producing and reproducing discourses that become incorporated into a society's subjectivities. When a specific discourse becomes normalised, any critical consciousness is dissolved, and different agents in the social network become convinced that the social system is the way that it has always been and the way that it should be and that it cannot be transformed. This way keeps the subaltern classes voluntarily subordinate, uncritical and politically passive (Stoddart, 2007:206). The dominant discourse does not allow for other, oppositional discourses to take root, to ensure that it maintains hegemonic power (Brigg, 2002:427). When a discourse has been incorporated into a society's individual subjectivities, social inequality becomes accepted, and the discourse has reached its aim of producing hegemonic effects (Stoddart, 2007:208).

In this regard, the mainstream development discourse has proven extremely efficient in producing the view of a Third World that needs to be liberalised from a miserable, undesired state of 'underdevelopment' (Escobar, 1995:9). The colonialist ideals of what a 'good' society should look like (the Western image of 'developed'), as well as what interventions can lead to this desired state of development, are presented as scientific knowledge. This expert knowledge is produced by the dominant Western ideal of a 'good' 
society and presented as universally applicable. The dominant development discourse ignores and subordinates competing conceptions of a 'good' society (Ziai, 2013:130), and dissolves any critical consciousness regarding development. Under the auspice of attaining a higher goal for the greater good, the development ideology legitimises the unsolicited intervention into the lives of 'less-developed' societies (Ziai, 2017:2548). Nevertheless, instead of leading to the emancipation of the 'underdeveloped' world, the development discourse has proven to be a tool used for hegemony, domination and control (Esteva \& Escobar, 2017:2567). Development is thus criticised for its authoritarian and hegemonic nature (Harcourt, 2017:2709; Ziai, 2013:130).

This argument had proven to hold even after colonialism when states became mechanisms for exploitation after trusteeship was handed over to the national elites (Ziai, 2013:130). In the field of entrepreneurship, this is illustrated by a phenomenon that Honig (2017) calls compensatory entrepreneurship. He defines it as:

the political endorsement of entrepreneurial promotion activities, including training, incubation, and media dissemination, for the primary objective of maintaining political and/or economic control of one population over another.

By claiming that entrepreneurship guarantees economic emancipation and that anyone can be an entrepreneur, the mainstream narrative convinces the subaltern classes that their inability to capitalise on entrepreneurial development and support initiatives can only be blamed on their shortcomings or lack of motivation. The political elite is thus exempted from any responsibility towards the economic emancipation of the unemployed (Honig, 2018). In this manner, the entrepreneurship ideology becomes supportive of political hegemony and epistemic violence (Authors, 2020).

EDA not only fails to produce viable enterprises that contribute significantly to job creation and economic growth, but it is also used as a tool that justified the exploitation and continued marginalisation of the economically marginalised. From a post-development theory perspective, it is thus propositioned that:

P8: The further implementation of entrepreneurship development projects in the name of emancipation and liberation of the economically marginalised is not justified.

\section{Conclusion}

'Entrepreneur' is a heterogeneous concept, and the current theoretical framing of entrepreneurship includes several diverse phenomena under the same conceptual umbrella. However, this conceptual umbrella's boundaries have been drawn and redrawn to such an extent that it has come to include more or less all of humanity (Poole, 2018:41). What is more, mainstream research is continuously presenting 'entrepreneurship' as a homogenous concept (Calás et al., 2009:553).

The mainstream entrepreneurship discourse paints it as a silver bullet for job creation and poverty alleviation and fails to recognise the archaeological ruins left by entrepreneurship's failure to deliver on this promise. Based on this unproven discourse, development 
organisations and governments in the Global South continuously implement numerous policies and interventions to stimulate the SME sector, also in economically marginalised communities, believing that it will be a catalyst for growth, job creation and poverty reduction. Although entrepreneurship has become appropriated as a development apparatus, it largely remains researched from a purely economic perspective (Steyaert \& Katz, 2004a). This article argues that mainstream entrepreneurship theory had entered the same theoretical impasse that mainstream development theory encountered in the 1980s when post-development theorists concluded that "no amount of improved implementation will be useful; rather we need to reconsider the ideas informing the Project" (Matthews, 2005:96).

The phenomenon 'entrepreneurship as a development apparatus' (EDA) is introduced and subjected to the rich, ongoing debate on development, alternative development and post-development. Reframing entrepreneurship within a development framework provides new insights into the failure of EDA to live up to its promise of job creation and economic development. Specifically, post-development theory provides a tool for deconstructing mainstream entrepreneurship theory, exposing the development ideology and assumptions inherent in EDA. The aim is not to merely provide a dualistic opposition to mainstream entrepreneurship theory, but to open a wider, dynamic, critical debate of EDA. By subjecting mainstream entrepreneurship theory to post-development theory critique, this article extends on the nascent field of critical entrepreneurship studies by drawing several conclusions for further investigation. These include highlighting EDA's colonialist roots, its potentially devastating effects on the environment, the use of EDA as a tool for exploitation, its inability to redress the injustices of the past and how EDA is used to legitimise the field of entrepreneurship.

Based on these conclusions, this study proposes that the implementation of entrepreneurship development projects in the name of emancipation and liberation of the economically marginalised can no longer be justified. However, this cannot be done when the naturalised belief is that EDA is a silver bullet for job creation and economic development. This article thus calls for the denaturalisation of the EDA narrative, similar to what post-development theorists call the 'unmaking' of development (Harcourt, 2017:2705). Drawing from post-development theory, it is clear that critique can influence mainstream theory and that academic discourses can change public opinions. Members of the scholarly community have to take up their responsibility as agents of social change to lead this process of unlearning the taken-for-granted assumptions and create a new narrative about EDA. The myth of 'the entrepreneur', created by mainstream entrepreneurship research, has to be undone by presenting new scientific knowledge.

A first step would be to unbundle the ever-growing conceptual framework of mainstream entrepreneurship. The current conceptual frame is proving grossly inadequate to explain the complexity of the EDA phenomenon. Continuously redefining entrepreneurship to include all types of social phenomena will not bring the paradigmatic break and new narrative needed to move beyond the failure of EDA. This article thus calls for the rejection of the entire notion of EDA as a form of entrepreneurship. Rather, the phenomenon has 
to be reconceptualised as a complex, interdisciplinary field of study that is rigorously researched beyond the constraints of mainstream entrepreneurship theory.

The mainstream narrative regarding entrepreneurship has to be unlearned. The myth of 'the entrepreneur' has to be undone. The conceptual entrepreneurship frame has to be unbundled to determine which phenomena have to be included in the frame going forward, and which phenomena have to be untrepreneured.

\section{References}

Achtenhagen, L. \& Welter, F. (2007). Media discourse in entrepreneurship research. In: H. Neergaard \& J.P. Ulhoi (Eds.). Handbook of Qualitative Research Methods in Entrepreneurship. Cheltenham: Edward Elgar Publishing.

Alvesson, M. \& Deetz, S. (2000). Doing Critical Management Research. London: Sage. https://doi.org/10.4135/ 9781849208918

Alvesson, M. \& Sandberg, J. (2013). Has management studies lost its way? Ideas for more imaginative and innovative research. Journal of Management Studies, 50(1):128-152. https://doi.org/10.1111/j.1467-648 6.2012.01070.x

Alvesson, M. \& Willmott, H. (2003). Studying management critically. London: Sage.

Anand, S. \& Sen, A. (1994). Human Development Index: Methodology and Measurement. New York: Office, Human Development Report.

Andreasson, S. (2017). Fossil-fuelled development and the legacy of post-development theory in twenty-firstcentury Africa. Third World Quarterly, 38(12):2634-2649. https://doi.org/10.1080/01436597.2017.1334544

Brigg, M. (2002). Post-development, Foucault and the colonisation metaphor. Third World Quarterly, 23(3):421-436. https://doi.org/10.1080/01436590220138367

Bygrave, W. (2007). The entrepreneurship paradigm (I) revisited. In: H. Neergaard \& J.P. Ulhoi (Eds.). Handbook of Qualitative Research Methods in Entrepreneurship. Cheltenham: Edward Elgar Publishing.

Calás, M.B., Smircich, L. \& Bourne, K.A. (2009). Extending the boundaries: reframing "entrepreneurship as social change" through feminist perspectives. The Academy of Management Review, 34(3):552-569. https:// doi.org/10.5465/amr.2009.40633597

Da Costa, A.D.S.M. \& Silva Saraiva, L.A. (2012). Hegemonic discourses on entrepreneurship as an ideological mechanism for the reproduction of capital. Organization, 19(5):587-614. https://doi.org/10.11 77/1350508412448696

Demaria, F. \& Kothari, A. (2017). The post-development dictionary agenda: paths to the pluriverse. Third World Quarterly, 38(12):2588-2599. https://doi.org/10.1080/01436597.2017.1350821

Escobar, A. (1992). Reflections on 'development'. Futures, 24(5):411-436. https://doi.org/10.1016/0016-3287 (92)90014-7

Escobar, A. (1995.) Encountering development: the making and unmaking of the third world. Princeton, NJ: Princeton University Press.

Esteva, G. \& Escobar, A. (2017). Post-development @ 25: on 'being stuck' and moving forward, sideways, backward and otherwise. Third World Quarterly, 38(12):2559-2572. https://doi.org/10.1080/01436597.201 7.1334545

Esteva, G. \& Prakash, M.S. (1998). Beyond development, what? Development in Practice, 8(3):280-296. https://doi.org/10.1080/09614529853585

Fairclough, N. (2013). Critical Discourse Analysis: The Critical Study of Language. Hoboken, NJ: Taylor and Francis. https://doi.org/10.4324/9781315834368 
Fournier, V. \& Grey, C. (2000). At the critical moment: conditions and prospects for critical management studies. Human Relations, 53(1):7-32. https://doi.org/10.1177/0018726700531002

Goldman, G. (2016). On the possibility of fostering critical management studies in South Africa. Acta Commercii, Supplement 1, 16(2). https://doi.org/10.4102/ac.v16i2.415

Hamilton, L. (2019). Amartya Sen. Cambridge: Polity Press.

Harcourt, W. (2017). The making and unmaking of development: using post-development as a tool in teaching development studies. Third World Quarterly, 38(12):2703-2718. https://doi.org/10.1080/01436597.2017. 1315300

Harriss, J. (2005). Great promise, hubris and recovery: a participant's history of development studies. In: U. Kothari (Ed.). A Radical History of Development Studies: Individuals, Institutions and Ideologies. London: Zed Books.

Honig, B. (2017). Compensatory entrepreneurship: avoiding the pitfalls of global isomorphic entrepreneurship research and activities. Revista de Empreendedorismo e Gestão de Pequenas Empresas (Regepe), 6(3):452-465. https://doi.org/10.14211/regepe.v6i3.723

Honig, B. (2018). Entrepreneurship as a political tool: the implications of compensatory entrepreneurship. In: C.H. Matthews \& E.W. Liguori (Eds.). Annals of Entrepreneurship Education and Pedagogy. Cheltenham: Edward Elgar Publishing. https://doi.org/10.4337/9781788114950.00019

Jäger, S. \& Maier, F. (2009). Theoretical and methodological aspects of Foucauldian critical discourse analysis and dispositive analysis. In: R. Wodak \& M. Meyer (Eds.). Methods for Critical Discourse Analysis. 2nd edition. London: Sage.

Jones, C. \& Murtola, A.M. (2012). Entrepreneurship and Expropriation. Organization, 19(5):635-655. https:// doi.org/10.1177/1350508412448694

Kuada, J. (2015). Entrepreneurship in Africa: A Classificatory Framework and a Research Agenda. African Journal of Economic and Management Studies, 6(2):148-163. https://doi.org/10.1108/AJEMS-10-2014-0076

Kuratko, D.F. (2005). The emergence of entrepreneurship education: development, trends, and challenges. Entrepreneurship Theory and Practice, 29(5):577-597. https://doi.org/10.1111/j.1540-6520.2005.00099.x

Matthews, S. (2004). Post-development theory and the question of alternatives: a view from Africa. Third World Quarterly, 25(2):373-384. https://doi.org/10.1080/0143659042000174860

Matthews, S. (2005). Attaining a better society: critical reflections on what it means to be 'developed'. Theoria, 106:93-118. https://doi.org/10.3167/004058105780929228

Matthews, S. (2017). Colonised minds? Post-development theory and the desirability of development in Africa. Third World Quarterly, 38(12):2650-2663. https://doi.org/10.1080/01436597.2017.1279540

Nandy, A. (1997). Colonization of the mind. In: M. Rahnema \& V. Bawtree (Eds.). The Post-Development Reader. London: Zed Books.

Naudé, W. (2011). Entrepreneurship is not a binding constraint on growth and development in the poorest countries. World Development, 39(1):33-44. https://doi.org/10.1016/j.worlddev.2010.05.005

Naudé, W.A. \& Havenga, J.J.D. (2005). An overview of African entrepreneurship and small business research. Journal of Small Business \& Entrepreneurship, 18(1):101-120. https://doi.org/10.1080/08276331.2005.10593334

Nederveen Pieterse, J. (1998). My paradigm or yours? Alternative development, post-development, reflexive development. ISS Working Paper Series/General Series, 2291-2336. https://doi.org/10.1111/1467-7660.00081

Nederveen Pieterse, J. (2000). After post-development. Third World Quarterly, 21(2):175-191. https://doi. org/10.1080/01436590050004300

Neergaard, H. \& Ulhoi, J.P. (2007). Introduction: Methodological Variety in Entrepreneurship Research. In: H. Neergaard \& J.P. Ulhoi (Eds.). Handbook of Qualitative Research Methods in Entrepreneurship. Cheltenham: Edward Elgar Publishing. https://doi.org/10.4337/9781847204387

Ogbor, J.O. (2000). Mythicizing and reification in entrepreneurial discourse: ideology-critique of entrepreneurial studies. Journal of Management Studies, 37(5):605-635. https://doi.org/10.1111/1467-6486.00196 
Poole, D.L. (2018). Entrepreneurs, entrepreneurship and SMEs in developing economies: how subverting terminology sustains flawed policy. World Development Perspectives, 9:935-942. https://doi.org/10.1016/j. wdp.2018.04.003

Ruggunan, S.D. (2016). Decolonising Management Studies: A Love Story. Acta Commercii, Supplement 1, 16(2). https://doi.org/10.4102/ac.v16i2.412

Sachs, W. (1992). The Development Dictionary: A Guide to Knowledge as Power. London: Zed Books.

Sachs, W. (2017). The sustainable development goals and "Laudato si": varieties of post-development? Third World Quarterly, 38(12):2573-2587. https://doi.org/10.1080/01436597.2017.1350822

Sen, A. (2001). Development as freedom. New York: Anchor Books.

Shane, S. (2009). Why encouraging more people to become entrepreneurs is bad public policy. Small Business Economics, 33(2):141-149. https://doi.org/10.1007/s11187-009-9215-5

Smit, M.M. \& Pretorius, M. (2021). Academic hubris in the scholarly entrepreneurship discourse. Acta Commercii. Forthcoming.

Steyaert, C. \& Katz, J. (2004). Reclaiming the space of entrepreneurship in society: geographical, discursive and social dimensions. Entrepreneurship \& Regional Development, 16(3):179-196. https://doi.org/10.1080/ 0898562042000197135

Stoddart, M.C.J. (2007). Ideology, hegemony, discourse: a critical review of theories of knowledge and power. Social Thought and Research, 28:191-225. https://doi.org/10.17161/STR.1808.5226

Tedmanson, D., Verduijn, K., Essers, C. \& Gartner, W.B. (2012). Critical perspectives in entrepreneurship research. Organization, 19(5):531-541. https://doi.org/10.1177/1350508412458495

Urban, B. (2010). Frontiers in entrepreneurship. Heidelberg: Springer. https://doi.org/10.1007/978-3-642-04502-8

Van der Linde, T. (2016). What is critical in critical management studies. Acta Commercii, Supplement 1, 16(2). https://doi.org/10.4102/ac.v16i2.424

Verduijn, K., Dey, P., Tedmanson, D. \& Essers, C. (2014). Emancipation and/or oppression? Conceptualizing dimensions of criticality in entrepreneurship studies. International Journal of Entrepreneurial Behaviour and Research, 20(2):98-107. https://doi.org/10.1108/JJEBR-02-2014-0031

Verduijn, K. \& Essers, C. (2013). Questioning dominant entrepreneurship assumptions: the case of female ethnic minority entrepreneurs. Entrepreneurship Regional Development, 25(7-8):612-630. https://doi.org/1 $0.1080 / 08985626.2013 .814718$

Wilson, K. (2017). Worlds beyond the political? Post-development approaches in practices of transnational solidarity activism. Third World Quarterly, 38(12):2684-2702. https://doi.org/10.1080/01436597.2017.1354694

Zhao, H., Seibert, S.E. \& Lumpkin, G.T. (2010). The relationship of personality to entrepreneurial intentions and performance: a meta-analytic review. Journal of Management, 36(2):381-404. https://doi.org/10.1177/ 0149206309335187

Ziai, A. (2004). The ambivalence of post-development: between reactionary populism and radical democracy. Third World Quarterly, 25(6):1045-1060. https://doi.org/10.1080/0143659042000256887

Ziai, A. (2013). The discourse of "development" and why the concept should be abandoned. Development in Practice, 23(1):123-136. https://doi.org/10.1080/09614524.2013.752792

Ziai, A. (2017). Post-development 25 years after the development dictionary. Third World Quarterly, 38(12): 2547-2558. https://doi.org/10.1080/01436597.2017.1383853 